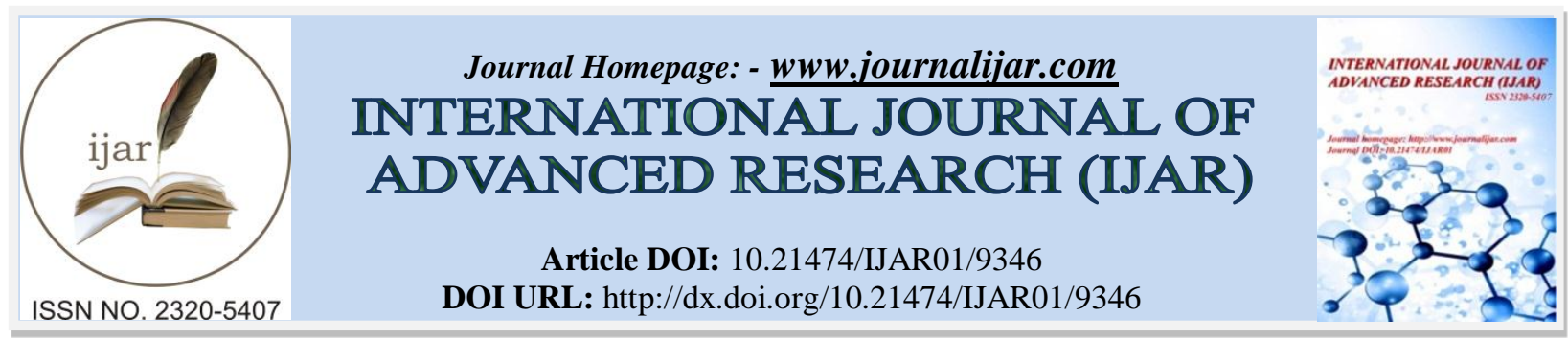

RESEARCH ARTICLE

\title{
BACHELOR OF SCIENCE IN EDUCATION PROGRAM FACTORS: THEIR INFLUENCE ON THE LICENSURE EXAMINATION PERFORMANCE AND EMPLOYABILITY OF THE GRADUATES.
}

Evelyn L. Balaoro, Ed. D.

Faculty, College of Teacher Education, Laguna State Polytechnic University.

\section{Manuscript Info}

Manuscript History

Received: 05 May 2019

Final Accepted: 07 June 2019

Published: July 2019

\section{Abstract}

This study determined the Bachelor of Science in Education Program factors and their influence on the Licensure Examination Performance and employability of the graduates covering from the school years 2016-2017.

The present study was concerned about the licensure examination and performance of the graduates in terms of instructional facilities, performance, administration, faculty, research, extension, plant facilities, laboratory equipment and library. It also looked into the performance of the graduates.

The respondents of the study are composed of 166 graduates from 2016-2017 who took up the Licensure Examination for Teaches from Laguna State Polytechnic University, Sta. Cruz Main Campus.

The results of this study showed that female individuals dominated the teaching professions and almost half of the respondents are single. In terms of educational qualification, most of them are Bachelor of Science in Education graduates. However, only a few pursued in Master's program. It was found out that the present position obtained by the BSED graduates was teaching with a frequency of 115 or $69.3 \%$. While the levels of employability of the graduates, most of them were employed with a frequency of 92 or $55.4 \%$. Most of the respondents were employed and permanent in an institution. In general, the respondents took up the Licensure Examination only once with a frequency of 159 or $95.8 \%$. Most of the respondents had a board rating of 75.0 with a frequency of 83 or $50 \%$ and had only 1-4 years in teaching with a frequency of 139 or $83.7 \%$ questionnaire was used as a major tool in gathering the data needed. The statistical treatment was as follows: frequency distribution, percentage statistics and weighted mean. The data gathered used the stepwise multiple regression analysis in order to determine the influence of LET on the employability of the graduates.

The independent variables considered in this study are as follows: instructional facilities, administration, faculty, research, extension, plant facilities, laboratory equipment and library. The person-related factors include age, gender, civil status, area of specialization, board rating and number of LET taken. The dependent variables were represented by the Licensure examination for Teachers and the employability of the graduates. 
It was found out that the LET performance and employability of the graduates have to be very evident and functioning well in terms of faculty, curriculum, research, extension, library, plant facilities,

laboratory and administration. The LET performance and employability of the graduates are predicted by years of teaching, eligibility and training. But the dependent variable could not be predicted by moderating variables represented by Pearson-related factors. Furthermore, the researcher would like to find out the strength and weaknesses of the program and how this may help the Bachelor of Science in Education students to pass the Licensure examination.

Copy Right, IJAR, 2019,. All rights reserved.

\section{Introduction:-}

Education plays a major role in human development. As it was stated in the 1987 Constitution. "The State shall protect and provide the right of all the citizens to quality education at all levels and shall take appropriate steps to make such education accessible to all". This Constitutional mandate specifies the government's responsibility in upgrading the educational system provide economic and gainful employment. Thus, these different curricula offered by an institution cater to the employability of the graduates. However, the study conducted by Sabas (2001) confirmed the general observation that teacher-training colleges have failed in producing teachers who are adequately equipped with content knowledge of teaching methodologies. Furthermore, it was also observed that many education graduates failed in the Licensure Examination; thus, they became unemployed or underemployed. The Licensure Examination for Teachers administered by the Professional Regulatory Commission that enhances the professionalism of teachers who would engage in teaching profession. But for certain reasons, there are colleges who failed to provide quality education that will enhance the skills and knowledge of the students and produce quality graduates. As inquired by Dr. Aniceto Orbeta, Senior Research of the Philippine Institute for development studies (PDIS), can educational planning be solve by unemployment? He stressed that educational planning is commonly justified by the high unemployment rates of educational workers. The unemployment rates, he pointed out are taken as an indication of the mismatch between what is produced by the educational sector and what the labor market's needs. (Manila Bulletin, August 3, 2003).

This implies that the curriculum should match the needs of the industry sector that will help the college graduates in their employment. This study will give the different institutions or state universities and colleges what fields of studies and activities are worthy to the graduates.

\section{Objectives:-}

The study would like to examine the effective guidelines for the refinement and revisions of existing program to make it relevant to the present need of the educational sector. Specifically, this study sought to answers the following questions:

1. What is the profile of the graduates in terms of age, gender, civil status, educational qualification, present position, level employability, present appointment status in the institution or company, types of in-service training attended/workshop or conferences and number of years in training?

2. How do the faculty and students perceive the effectiveness of the LSPU tertiary programs with respect to the following variables such as curriculum, administration, faculty, plant and facilities, laboratory facilities, library, research and extension?

3. What is the level of employability of graduates in terms of the following waiting time for employment, status of employment?

4. Which of the BSED program factors, singly or combination, influence the employability and LET performance of the graduates?

5. How do the following moderator variables affect the relationship between the BSED program factors and the two dependent variables and employability of the graduates?

\section{Methodology:-}

The study is a descriptive method of research in conducting an investigation. The investigation was conducted in the four campuses of LSPU namely LSPU Sta. Cruz Main Campus with 117 respondents, and 49 from San Pablo 
respectively. The data were tabulated and analysed through descriptive statistics such as mean and standard deviation.

\section{Literature Review:}

The value of educational system is to be found in the curriculum of the schools, if it provides all the learning capacities and expenses for the students in their everyday activities. One of the main problems of educational quality concerns on the appropriateness of the curriculum, the quality of education, and the effectiveness of the teaching. Curriculum of a school is the formal and informal content and process by which learners gain knowledge and understanding, develop skills and alter attitudes, appreciations and values under the auspices of that school (Doll, 1982).

Gaudencio (1998) identifies the five purposes of the curriculum study; 1. Meeting of cultural demands, 2. Solving instructional problems, 3. Changing peoples' way of behaving, 4. Changing perceptions, 5. Improving students' experiences.

Arroco (2001) cite that the curriculum program should be evaluated. He also mentioned that evaluation of the program serves variety of functions. First, it provides reliable and valid information about the over-all performance of an activity program. It reveals the extent to which particular goals and objectives. Second, it contributes to the clarification and of critique of values, which underlie the selection of goals and objectives. Third, it contributes, to the application of other forms of problems analytic method about restructuring and improvement of the program. If there is inadequacy of the program, this may contribute to the redefinition of the objectives.

He also cited that the purpose of the program or curricular assessment studies is not to identify the significant weakness or problem of present program but also to determine how they can be improved or designed. Such ideas may also deal with the measures of inputs or antecedents variables, transactions, processes, outputs and outcomes of the curricular program.

The studies cited above are similarly related to the present study the difference lies only on the variables.

Cortez (1998) made an investigation about the school administration in Bataan. He made mention that school administration is not an end but rather the means to achieve the goals of education. It is an effective tool by which the aim of education can be achieve. He also cited that school administration is an agency that provides a condition for favourable good teaching and learning. Thus, it contributes greatly by providing the learners and equipping them with proper environment for work and study.

The importance of school administrators greatly affects the teaching and learning of the young. Thus, effective school administration serve as the major role in learning. Likewise the different leadership styles play the role in directing and guiding the teachers. Thus, they produce efficient and effective agents of knowledge that respond to the needs of the society.

Jaraplasan (2003) stated that the heart of education was duly given to the administration. Administration performed the planning and organizing, provided leadership, supervisory skills and personnel management. Thus, it means that administration should work hard for the attainment of each objective with regards to the mission and vision of an institution. Lacson (1998) revealed that the quality of education depends largely on administration. According to her, the concept generally prescribed under the terms supervision, management and leadership. She defined administration as the art of putting together people, programs, and resources in order to attain the school objectives. These administrative functions includes planning, evaluating and budgeting.

The above literatures and studies cited above are similarly related to the present study because it focuses on the influence of BSED Program factors on the performance and employability of the graduates.

In order to attain good quality of education one must consider the instructional facilities, which provides a vital role in learning. Adequate facilities should be given emphasis by an administrators because instructional facilities will help the learners or students to become active and globally competitive. Pailan (2001) stated also that adequate instructional facilities, equipment and tools play a vital role in making learning more meaningful and effective. He 
further stressed that vocational schools must be adequately equipped with more highly advanced instructional materials, equipment's, for the development of these young professional in the near future.

Another factor that contributes to the development of the youth are the faculties of which according to Diaz (2001) the growing concern in the Philippines about the decaying quality education should be given emphasis. The rise of global competitiveness and expanded opportunities of which the education system should be more flexible and responsive to the challenging needs of the future teachers. On the other hand, the study of Espinueva (2002) is similarly related to the present study because he cited that the indicator of quality of education is the faculty distinction requirement. He added that the faculty is one of the stronger partners of quality education. Today, most of the graduates of bachelor is upgrading themselves by enrolling to the post graduate course. The reason, for the upgrading of the library.

The library is a place where books and manuals, journals, microfilms and audio visuals are kept and organized to support the cultural, information, recreational, and educational needs of the general public or specific group of learners.

Based on Cortez (2000) stressed that the academic library is the heart of nay institutional learning. It is where the repository of knowledge and information is found. He further stressed that the library among its great functions is to support the curricular, instructional research and extension services. He mentioned the library services such as the following:

1. Adequacy of library collections of books, journals and other learning materials

2. Proper ventilation for the learners.

3. Control and safety measures to safeguard the library.

4. Library funds based on the needs of the library.

5. Library fees should spent for the growth and development of library ensuring and sharing resources with the community.

Before teachers practice their profession to both private and public they are required to pass the Professional Board Examination for Teachers (PBET) now the Licensure Examination for Teachers (LET) by virtue of Republic Act No. 7838, otherwise known as the Philippine Teachers Professionalization of 1994 with a grading of $75 \%$ to pass the examination.

Angeles (2000) cited that in "Rationalization of Higher Education in the Philippines the licensure examinations given by the PRC are considered an indicators of quality of Teachers in joining the teaching position whether private or public." Nada (1995) in her study entitled "Predictors of Performance in the Professional Board Examination for Teachers (PBET) among the graduates of the PNU revealed that this Institution earned reputation as one of the leading teachers in our country. However, this recognition of excellence, PNU is not exempted from the problem of having all its examinee pass the Professional Board Examination for Teachers or Licensure Examination for Teachers.

Sabas (2001) revealed that LET greatly enhances professional status and accountability for those who decide to become teachers. Without extensive and vigorous pre-service training one may fail for his competencies. PRC has challenged teacher educational institutions to provide more educational in- service training that produce our graduates of good quality and competent to teach. Thus, LET served as a stimulus for radical components in teacher training programs because it will serve as a continuous assessment of quality of preparation given by different training institutions for their future employment.

Bautista (1997) cited that employability of the graduates might possibly influence by various factors such as curriculum, teachers competence, adequacy of facilities and updated books given by the library.

\section{Discussion:-}

Table I: - presents the frequency and percentage distribution of the respondents in terms of age.

\begin{tabular}{|l|l|l|}
\hline Age & Frequency & Percentage Distribution \\
\hline 25 ears below & 88 & 53.0 \\
\hline $26-35$ years old & 76 & 45.70 \\
\hline
\end{tabular}




\begin{tabular}{|l|l|l|}
\hline 35 years old & 2 & 1.20 \\
\hline Total & 166 & 100.0 \\
\hline
\end{tabular}

Table 1 shows the age ranges of the respondents. Eight-eight (88) or $53 \%$ belong to 25 years of age; 76 or $45.70 \%$ belong to $26-35$ years of old; 2 or $1.20 \%$ belong to 35 years and above. The findings reveal that most of the respondents are newly graduates and belong to 25 years old below. The youngest respondents is 19 years old and the oldest is 41 years of age. Average age of the respondents is 25. 59. This implies that the teaching profession is dominated by the younger ones than the old ones.

Table 2:- Frequency and Percentage Distribution of the Respondents in Terms of Civil Status

\begin{tabular}{|l|l|l|}
\hline Gender & Frequency & Percentage Distribution \\
\hline Female & 138 & 83.1 \\
\hline Male & 28 & 16.9 \\
\hline Total & 166 & 100 \\
\hline
\end{tabular}

Table 2 shows the distribution of the respondents in terms of gender, 138 or $83.1 \%$ of the BSED graduates are female and 28 or $16.9(\%$ are male. Data show that female dominates teaching other male.

Table 3:- Frequency and Percentage Distribution of the Respondents in Terms of Civil Status

\begin{tabular}{|l|l|l|}
\hline Civil Status & Frequency & Percentage Distribution \\
\hline Single & 135 & 81.3 \\
\hline Married & 30 & 18.1 \\
\hline Total & 166 & 100 \\
\hline
\end{tabular}

Table 3 shows the distribution of respondents on civil status. One hundred thirty-five (135) or $81.3 \%$ of the BSED graduates were single; 30 or $18.1 \%$ were married graduates while 1 or $6 \%$ did not respond.

Table 4:- Frequency and Percentage Distribution of the Respondents in Terms of Educational Qualification

\begin{tabular}{|l|l|l|}
\hline Educational Qualification & Frequency & Percentage Distribution \\
\hline BSED Graduates & 140 & 84.3 \\
\hline BSED/MA Units & 25 & 15.1 \\
\hline Others & 1 & 6 \\
\hline Total & 166 & 100 \\
\hline
\end{tabular}

Table 4 shows the educational qualification of the respondents. The data indicate that 140 or $84.3 \%$ were BSED graduates; while 25 or $15.1 \%$ have MA units. The data show that most of the BSED graduates are taking up MA units for their professional growth.

Table 5:- Frequency and Percentage Distribution of BSED Graduate in terms of Present Position

\begin{tabular}{|l|l|l|}
\hline Present Position & Frequency & Percentage \\
\hline Teacher & 115 & 69.0 \\
\hline Foreman & 1 & 0.6 \\
\hline Laborer/Operator & 30 & 18.0 \\
\hline Employee & 9 & 5.4 \\
\hline Others & 5 & 3.0 \\
\hline No response & 6 & 4.0 \\
\hline Total & 166 & 100 \\
\hline
\end{tabular}

Table 5 shows the distribution of BSED graduates based on their present position. One hundred fifteen (115) or $69 \%$ are holding the teacher position. Followed by 30 or $18 \%$ occupying the position of labourer/operator. Nine (9) or 5.4\% were employees in a firm. One or $0.6 \%$ is a foreman. However, 6 or $4 \%$ have no response at all.

Table 6:- Frequency and Percentage Distribution of the Respondents in Terms of levels of Employability

\begin{tabular}{|l|l|l|}
\hline Levels of Employability & Frequency & Percentage \\
\hline Employed & 127 & 76 \\
\hline Unemployed & 6 & 4 \\
\hline Underemployed & 30 & 18 \\
\hline No response & 3 & 2 \\
\hline
\end{tabular}




\begin{tabular}{|l|l|l|}
\hline Total & Total & 100 \\
\hline
\end{tabular}

As indicated in Table 6, one hundred twenty seven or $76 \%$ were employed; followed by 30 or $18 \%$ who were underemployed; 6 or $4 \%$ were unemployed. Among the employed respondents, 32 or $19.3 \%$ were self-employed. Data show that most of the BSED respondents were employed to different institutions or company. Through this, relevance of instruction and training learned by the students is important to the employability of the graduates. The present findings conform to the study of Bautista (1997) that the levels of employability of the graduates might possibly influence by various factors. These factors include curriculum, teacher competence and adequacy of facilities and replication of industry.

Table 7:- Frequency and Percentage distribution of the Respondents in Terms of Appointment Status

\begin{tabular}{|l|l|l|}
\hline Appointment Status & Frequency & Percentage Distribution \\
\hline Permanent & 77 & 46.4 \\
\hline Probationary & 27 & 16.3 \\
\hline Temporary & 43 & 25.9 \\
\hline No response & 19 & 11.4 \\
\hline Total & 166 & 100 \\
\hline
\end{tabular}

Table 7 shows the data in terms of present appointment status of 166 respondents. There were 77 or $46.4 \%$ who were permanent, followed by 43 or $25.9 \%$ who were temporary; 27 or $16.3 \%$ probationary and 19 or $11.4 \%$ have no response at all. Findings reveal that more than three-fourths of the graduates were permanent status in their job whether in private or public institution or agency.

Table 8:- Frequency and Percentage Distribution of Respondents in Terms of Types of Eligibility

\begin{tabular}{|l|l|l|}
\hline Types of Eligibility & Frequency & Percentage \\
\hline Civil Service Eligibility & 1 & .6 \\
\hline PBET & 1 & .6 \\
\hline LET & 155 & 93.4 \\
\hline Career Professional & 7 & 4.2 \\
\hline Others & 2 & 1.2 \\
\hline Total & 166 & 100 \\
\hline
\end{tabular}

Table 8 shows the distribution of the respondents in terms of types of eligibility. The table shows that 155 or $93.4 \%$ were Licensure Examination for Teacher passers, followed by 7 or $4.2 \%$ who were career professional passers. The civil service eligible is 1 or $6 \%$. Professional Board Examination for Teacher passer is also 1 or 6\%; 2 or 1.2\% belong to other types of eligibility.

Table 9:- Frequency and Percentage Distribution of the respondents in terms of Number of LET Taken

\begin{tabular}{|l|l|l|}
\hline No. of Times of LET Taken & Frequency & Percentage Distribution \\
\hline Once & 159 & 95.8 \\
\hline Twice & 2 & 1.2 \\
\hline No. of response & 5 & 3 \\
\hline Total & 166 & 100 \\
\hline
\end{tabular}

Table 9 shows the number of times the 166 respondents took up LET One hundred fifty nine (159) or $95.8 \%$ took up the LET on once; 2 or $1.2 \%$ took up LET twice; while 5 or $3 \%$ have no response at all. It is very evident that majority of the graduates passed LET.

Table 10:- Frequency and Percentage Distribution of the Respondents in Terms of waiting Time

\begin{tabular}{|l|l|l|}
\hline Waiting Time (No. of Months) & Frequency & Percentage Distribution \\
\hline 3 & 45 & 27.1 \\
\hline 5 & 10 & 6.0 \\
\hline 6 & 69 & 41.6 \\
\hline 7 & 1 & 0.6 \\
\hline 8 & 23 & 13.9 \\
\hline 10 & 1 & 0.6 \\
\hline
\end{tabular}




\begin{tabular}{|l|l|l|}
\hline 12 & 13 & 7.8 \\
\hline 17 & 1 & 0.6 \\
\hline 24 & 1 & 0.6 \\
\hline 36 & 2 & 1.2 \\
\hline Total & 166 & 100 \\
\hline
\end{tabular}

Table 10 shows that the shortest waiting time was three months and the longest was three years. Forty five (45) or $27.1 \%$ have awaiting time of 3 months; 69 (41.6\%) have a waiting time of 6 months; 23 (13.9\%) 8 months waiting time; 13 or $7.8 \%$ have a waiting time of 12 months. Three respondents $(1.8 \%)$ reported to have the longest waiting time of 24 months and above. Only one respondent (0.6\%) each reported to have waited 7, 8. 17 and 24 months respectively.

Table 11:- Frequency and Percentage Distribution of the Respondents in Terms of LET Rating

\begin{tabular}{|l|l|l|}
\hline LET Rating & Frequency & Percentage Distribution \\
\hline 75.0 & 83.0 & 50.0 \\
\hline 75.15 & 1 & .6 \\
\hline 75.30 & 1 & .6 \\
\hline 75.33 & 1 & .6 \\
\hline 75.36 & 1 & .6 \\
\hline 75.38 & 1 & .6 \\
\hline 75.40 & 2 & 1.2 \\
\hline 75.50 & 1 & .6 \\
\hline 75.60 & 1 & .6 \\
\hline 75.80 & 1 & .6 \\
\hline 76.0 & 56 & 33.7 \\
\hline 76.10 & 1 & .6 \\
\hline 76.15 & 1 & .6 \\
\hline 76.18 & 1 & .6 \\
\hline 76.20 & 3 & 1.8 \\
\hline 76.38 & 1 & .6 \\
\hline 76.40 & 1 & .6 \\
\hline 76.66 & 1 & .6 \\
\hline 77.0 & 5 & 3 \\
\hline 78.0 & 3 & 1.8 \\
\hline Total & 166 & 100 \\
\hline
\end{tabular}

Table 11 shows that one half of the respondents have LET rating of 75 frequency of 83 or $50 \%$. Fifty six (56) or $33 . \& \%$ got the rating of $76 ; 5$ or $3 \%$ got $77 \%$; and only 3 or $1.8 \%$ got 78 rating which was the highest rating reported. One factor to measure the employability of the graduates is the board rating if he/she passed the board. But most of the institutions or company accept those who have working experiences because they already know how to handle their work or job precisely. The present findings conform to Pena in his "PRC Board Examination and Globalization." He stressed that the study recently conducted by the PRC shows that for five years period, out of the total 840,148 examinees only 313,199 or $37 \%$ passed. Consequently, 526,949 or $63 \%$ of the examinees failed the board examinations.

It was supported by the study of Sabas (2001) revealed that the Licensure Examination for Teachers greatly enhances professional status and accountability for those who decide to become teachers. Without extensive and vigorous pre-service training one may fail for his competencies. The Professional Regulation has challenged teacher educational institutions to provide review centre that will cater the graduates to pass the board examination and produce of good quality output of those who would to become teachers in the future.

Table 12:- Frequency Distribution and Percentage Distribution o the respondents in Terms of Seminars and Trainings Attended

\begin{tabular}{|l|l|l}
\hline Seminars Training Attended & Frequency & Percentage Distribution
\end{tabular}




\begin{tabular}{|l|l|l|}
\hline International & 3 & 1.8 \\
\hline National & 6 & 3.6 \\
\hline Regional & 5 & 3.0 \\
\hline Division & 50 & 30.1 \\
\hline Institutional & 42 & 25.3 \\
\hline None at all & 60 & 36.1 \\
\hline Total & 166 & 100 \\
\hline
\end{tabular}

Indicated in Table 12 is the type of training, seminars, workshops and conferences attended by the 166 respondents. These seminars and training and others were classified into international, national, regional, divisional and institutional. Fifty (30.1\%) of the respondents reported to have attended divisional training; followed by 42 or $25.3 \%$ who had institutional training; 6 or $3.6 \%$ attended national training and 3 or $1.8 \%$ had international training. The data shows that the greater number of training attended, the more knowledge and skill will be acquired by the respondents that will help a lot to improve their profession as teachers.

Table 13:- Frequency and Percentage Distribution in Terms of Length of Service

\begin{tabular}{|l|l|l|}
\hline Length of Service & Frequency & Percentage \\
\hline $1-4$ years & 139 & 83.7 \\
\hline 5-9 years & 15 & 9.0 \\
\hline No response at all & 12 & 7.2 \\
\hline Total & 166 & 100 \\
\hline
\end{tabular}

Table 13 shows that 139 or $83.7 \%$ respondents have $1-4$ years in teaching, while 15 or $9 \%$ have $5-9$ years in teaching. The data revealed that majority of the respondents were still young in the teaching profession.

Table 14:- Mean Perception on the Effectiveness of LET Performance and Employability of the Graduates along the Areas of Faculty and Curriculum

\begin{tabular}{|l|l|l|}
\hline Item & Weighted Mean & Description \\
\hline Faculty & 4.52 & $\begin{array}{l}\text { Very evident or extreme and } \\
\text { functioning well }\end{array}$ \\
\hline Weighted Mean & 4.52 & $\begin{array}{l}\text { Very evident or extreme and } \\
\text { functioning well }\end{array}$ \\
\hline
\end{tabular}

Legend

$1-1.99$

2- 2.99

3- 3.99

4- 4.99

5
Description

Needed but missing

Limited and functioning poorly

Adequate and functioning fairly

Extensive and functioning fairly

Very evident or extreme and functioning well

As shown in the Table 14, the mean perception on the effectiveness of LET Performance and Employability of the Graduates indicated that faculty must have different training programs to enhance their knowledge in teaching. It was evidently shows that faculty was evident or extreme and functioning well. Findings reveal that the more competent a faculty are, the more they applied varied teaching techniques and strategies in different learning areas.

Table 15:- Mean Perception on the Effectiveness of LET Performance and Employability of the Graduates along the areas of Research and Library

\begin{tabular}{|l|l|l|}
\hline Item & Weighted Mean & Description \\
\hline Research & 4.46 & Extensive and functioning fairly \\
\hline Library & 4.64 & $\begin{array}{l}\text { Very evident or extreme and } \\
\text { functioning well }\end{array}$ \\
\hline Over-all Weighted Mean & 4.55 & $\begin{array}{l}\text { Very evident or extreme and } \\
\text { functioning well }\end{array}$ \\
\hline
\end{tabular}


Table 15 shows the mean perception on the effectiveness of LET performance and Employability of the Graduates along the areas of Research and Library. It indicates that every institution should have updated research and program department. That will caters changes and development to the needs of various sectors of society. The 4.46 mean perception of research with a description of extensive and functioning fairly means that there should be budget and benefits for those who have a lot of researches mostly for the faculty. In terms of the library which is the heart of an institution, it must be conducive to learning and studying.

The use of updated reading materials is a must. As shown in the table a mean perception of 4.64 has a description of very evident or extreme and functioning well. It means that, the more adequate the library is, the more effective knowledge the students can get.

Table 16:- Mean Perception on the Effectiveness of LET Performance and Employability of the Graduate along the areas of Plant Facilities, Laboratory and Administration

\begin{tabular}{|l|l|l|}
\hline Item & Weighted Mean & Description \\
\hline Plant facilities & 4.66 & $\begin{array}{l}\text { Very evident or extreme and } \\
\text { functioning well }\end{array}$ \\
\hline Laboratory & 4.29 & $\begin{array}{l}\text { Very evident or extreme and } \\
\text { functioning well }\end{array}$ \\
\hline Administration & 4.59 & $\begin{array}{l}\text { Very evident or extreme and } \\
\text { functioning well }\end{array}$ \\
\hline Over all weighted mean & 4.52 & $\begin{array}{l}\text { Very evident or extreme and } \\
\text { functioning well }\end{array}$ \\
\hline
\end{tabular}

Legend:

Range

$1-1.49$

$1.50-2.49$

$2.50-3.49$

$3.50-4.49$

$4.50-5.0$
Description

Needed but missing

Adequate and functioning poorly

Adequate and functioning fairly

Extensive and functioning fairly

Very evident or extreme and functioning well

Table 16 shows the effectiveness of LET performance and employability of graduates in terms of facilities, laboratory and administration. Plant facilities have a mean perception of 4.66 which is very evident that facilities like classrooms must be conducive to learning and provide educational activity to every student for them to be more active to learn. The laboratory has a mean of 4.29 with a description of extreme and functioning fairly which means that an institution has functional equipment in the laboratory to be use by the students. According to Magsajo (1999) he stated that laboratories and classrooms together also with the cafeteria, clinic and audio-visual room for the students to become effective and efficient.

A defined organization structure of the administration signifies their functions and duties with a mean perception of 4.59 with a description of very evident or extreme and functioning well. The three variables have an overall weighted mean of 4.52 with a description of very evident and functioning well. This indicates that the three variables plant facilities, laboratory, administration play a crucial role in an institution.

Table 17:- Profile Distribution with Reference to the Mean

\begin{tabular}{|l|l|}
\hline Item & Weighted Mean \\
\hline Age & 25.59 \\
\hline Board rating & 75.55 \\
\hline Waiting Time & 0,53 \\
\hline
\end{tabular}

Table 17 shows that majority of the respondents belong to 25 years old below with a weighted mean of 25.59 . This means that most of the respondents are young in the field of teaching. Board rating of the respondents indicates that more than half of the respondents have a Board rating of 75 with an average weighted mean of 75.55. The average mean of waiting time for the employment is 0.53 which indicates that the respondents took half year to find a job. 
Table 18:- Predictor of Waiting Time on Independent Variable

\begin{tabular}{|l|l|l|l|}
\hline Predictor & Beta & T & Significance \\
\hline Years of Teaching & -221 & -2.898 & .004 \\
\hline \multicolumn{2}{|c|}{ F- Value (ANOVA) $=8.398$}
\end{tabular}

Significance $\mathrm{F}=.004$

Among the independent variables of the study, only one predictor in the waiting time of the graduates was identified, which is years in teaching. The Beta coefficient indicates indicate that every unit increase in the years of teaching. There is a corresponding -221 unit decrease in the waiting time of the graduates. The higher the number of years of teaching decreases their waiting time. Therefore, waiting time and years of teaching are inversely correlated.

The Adjusted R-Square indicates that 0.43 present of the variance in the waiting time is indicated by the years of teaching of the graduates.

Table 19:- Regression of Level of Employment on Independent variable

\begin{tabular}{|l|l|l|l|}
\hline Predictor & Beta & $\mathrm{t}$ & Significance \\
\hline Eligibility & .172 & 2.759 & .006 \\
\hline Training & -.164 & -2.468 & .015 \\
\hline
\end{tabular}

Adjusted R Square $=.364 \quad F($ ANOVA) Significance $=32.475$

Among the independent variables of the study, only two predict the level of employment of the graduates. The Beta coefficient indicate that for every standard deviation unit increase in eligibility, there is a corresponding .172 standard deviation unit increase in the level of employment of the graduates. The eligibility that the graduates possess raises their level of employment. Those who are eligible find better jobs than those who are not eligible. The Beta coefficient indicate that for every standard deviation unit increase in the level of employment of the graduates. The eligibility that the graduates possess raises their level of employment. Those who are eligible find better jobs than those who are not eligible. The eligibility that the graduate applicants possess to qualify them to be employed as a teacher or other higher employment level either in public or private organizations. Those without eligibility settle as a office secretary, clerk or laborers.

Teaching job as a profession requires eligibility. Only those teachers who are board passers qualify to teach. Others who do not have such qualification settle jobs with lower category level and so in salary too.

Passing eligibility examinations indicates certain level of performance for the job. This indicator is given much weight by the Philippine Civil Service Commission. Teacher must be licensed to teach and those in the government must possess the minimum eligibility required by the job.

The Adjusted R Square indicates that 36.4 percent of the variance in the level of employment is explained by the eligibility of the graduates. Training significantly predicts the level of employment of graduates. The lesser the training the lower is the level of employment of the graduates. Training programs that are deemed relevant are given consideration for employment. As one industrialist said, "Give us graduates who possess desirable values and we will teach and train them for the job."

\section{Recommendations:-}

Based on the findings and conclusion, the following recommendations are drawn:

1. Since the respondents are newly graduates, it is recommended that these newly graduates should enrol in the Master's program in order to equip themselves with knowledge in the field they have chosen.

2. Inasmuch as facilities are significant predictors of performance in school-related factors, it is highly recommended that vocational and technical institutions provide functional and adequate equipment not only in laboratories and classrooms, but also in educational centre's like internet, audio-visual rooms and wellventilated library with updated books.

3. Since the tertiary program is very significant predictor to the BSED graduates curriculum, research and extension, library, plant facilities, laboratory and administration, it is recommended that the administrators emphasize budgeting. There should be adequate funds to the different programs. 
4. There should be enough materials and books to review by the BSED students to prepare them for the licensure examination for teachers.

5. There should be a review centre for the LET examinees.

6. There should be a research or follow-up study if the BSED graduates are employed or not in different institutions or companies. In that way, it can be determined if the curriculum is effective or not to the students.

\section{References:-}

1. Aquino, Gaudencio V. Curriculum Planning for Better Schools. Rex Printing Company, Inc., 1998.

2. De Leon, Hector S. Philippine Constitution. Rex Book Store, Manila, 1994.

3. Arroco, Jonathan C. "The Bachelor of Science in Industrial Education Program of the Bicol University College of Industrial Technology, Legaspi City: Its status and Prospects". Unpublished Master's Thesis. Bicol University, Legaspi City, 2001.

4. Manila Bulletin, page B-4, Sunday August 3, 2003.

5. Magsajo, Esmerita G. "Factors Affecting the Performance of Deans of College of Education". The Search Journal, Vol. 10 No. 1-2 January-December 1998.

6. Doll, Ronald C. Curriculum Improvement: Decision Making and Process. Allyn and Bacon, Inc., 1982.

7. Angeles, Emmanuel Y. "Educators Speak Rationalization of Higher Education in The Philippines." Manila Bulletin, June 23, 2000.

8. Bautista, Rudolph A. "employability of the Drafting Graduates of Bataan National School of Arts and Trades 1991-1995.” TUP Manila, 1997.

9. Espinueva, Ruperto C. Employability of the Bachelor of Science Industrial Education Graduates in Region IV." EARIST, Nagtahan, Sampaloc, Manila, 2002.

10. Pena, Reynato T. "Educators Speak". Manila Bulletin, January 30, 2000.

11. Pailan, Edwin A. "Performance of Bachelor of Science in Industrial Technology Students of LSPC: Input to Curriculum Enrichment. LSPC, Siniloan, Laguna, 2002.

12. Nada, Evelyn R. "Predictors of Performance in the Professional Board Examination for Teachers (PBET) among Graduates of the Philippine Normal University. Urios College, Butuan City, 1995.

13. Sabas, Glorietta B. "Factors Affecting the Performance of SVD Schools in the Licensure Examination for Teachers." Mariano Marcos University, 2001.

14. Diaz, Teresita N. "Determinants of Career Paths among Employed Graduates of the BSND Curriculum in Region III. Nueva Ecija University of Science and Technology, Cabanatuan City, 2001.

15. Cortez, Fernando P. "Administrative and Supervisory Skills of Elementary School Heads and Principals in the Division of Bataan:" Its Realation to Teacher's Job Satisfaction." Harvadian College, Bataan, 1998.

16. Lacson, Cecilia P. "Characteristics and Performance of Accredited and Non-Accredited Catholic Elementary School.” Search Journal, Vol. 10 No. 1-2 January-December 1998. 